\title{
PREPARATION AND PROPERTIES OF NATURAL RUBBER/ORGANO-MONTMORILLONITE: FROM LAB SAMPLES TO BULK MATERIAL
}

\author{
Aleksandra Ivanoska-Dacikj ${ }^{1,2^{*}}$, Gordana Bogoeva-Gaceva ${ }^{1}$, Aleksandra Buzarovska ${ }^{1}$, \\ Igor Gjorgjiev ${ }^{3}$, Luljeta Raka ${ }^{3}$ \\ ${ }^{1}$ Faculty of Technology and Metallurgy, Ss. Cyril and Methodius University, \\ Rugjer Bošković 16, Skopje, Republic of Macedonia \\ ${ }^{2}$ Research Center for Environment and Materials, Macedonian Academy of Sciences and Arts, \\ Krste Misirkov 2, 1000 Skopje, Republic of Macedonia \\ ${ }^{3}$ Institute of Earthquake Engineering and Engineering Seismology - IZIIS, \\ Ss. Cyril and Methodius University, Salvador Aljende 73, Skopje, Republic of Macedonia \\ ${ }^{4}$ Faculty of Natural Sciences and Mathematics, State University of Tetovo, \\ Ilinden nn, Tetovo, Republic of Macedonia \\ aivanoska@manu.edu.mk
}

Focusing on application aspects of the rubber nanocomposites and the production and testing of industrial-sized samples, this study was performed in two phases. First, natural rubber (NR)/organomontmorillonite (OMMT) nanocomposites containing 2-14 phr OMMT were prepared on a laboratorysized two-roll mill. The vulcanization behavior and mechanical properties of NR/OMMT composites were compared with a referent NR compound containing 60 phr carbon black (N330) as a reinforcing filler. The x-ray diffraction (XRD) analyses showed a predominant intercalated structure for all OMMT nanocomposites. As a result, the organoclay behaved as an effective reinforcement for NR, even at loadings as low as $2 \mathrm{phr}$. This nanocomposite exhibited an improvement in tensile strength of 29\% and in elongation at break of $61 \%$ in comparison with the referent NR/N330 compound. With the estimated optimal filler content, in the second phase, bulk NR/OMMT-5/steel samples were successfully produced for dynamic testing. The dynamic moduli were investigated by the method of forced vibrations. Compared to the NR/N 330 samples, NR/OMMT-5 samples showed improved hysteresis, with very low dissipating energy per cycle and significantly reduced Mullins effect.

Keywords: organo-montmorillonite; nanocomposites; natural rubber; dynamic properties

\section{ДОБИВАЫЕ И СВОЈСТВА НА ПРИРОДНА ГУМА НАПОЛНЕТА СО ОРГАНСКИ МОДИФИЦИРАН МОНТМОРИЛОНИТ: ОД ЛАБОРАТОРИСКИ ПРИМЕРОЦИ ДО МАСИВЕН МАТЕРИЈАЛ}

Истражувањата во овој труд се направени во две фази фокусирајќи се на применливоста на нанокомпозитите на база на гума и на добивањето и карактеризација на примероци со индустриски димензии. Прво беа подготвени лабораториски примероци нанокомпозити природна гума (NR)/органски модифициран монтморилонит (OMMT) co 2-14 phr OMMT на лабораториски двовалјак. Вулканизацијата и механичките својства на композитите NR/OMMT се споредувани со референтен примерок на природна гума наполнета со саѓи (N330). Рендгенската дифракција (XRD) покажа дека кај сите нанокомпозити со ОММТ доминира интеркалирана структура. Како резултат на тоа, органски модифицираната глина се однесува како ефикасен зајакнувач на природната гума, дури и при концентрации од само $2 \mathrm{phr}$. Нанокомпозитот се одликува со јачина на истегнување за $29 \%$ поголема од онаа на референтниот примерок со саѓи (NR/N330), како и со зголемено издолжување (за 61 \%). Во втората фаза, по определување оптимална количина на полнилото, произведени беа индустриски примероци NR/OMMT и сендвич-структура NR/OMMT-5/челична 
плоча наменета за динамичко тестирање. Динамичкиот модул на материјалот е испитуван со методот на принудни вибрации. Произведениот масивен нанокомпозитен материјал NR/OMMT-5 се одликува со подобрена хистереза, многу ниска енергија на дисипација за циклус и значително намален Mullin-ов ефект во споредба со референтниот материјал NR/N330.

Клучни зборови: органски модифициран монтморилонит; нанокомпозити; природна гума; динамички својства

\section{INTRODUCTION}

Natural rubber (NR) is used extensively in many different industrial and structural applications and products, since it can be compounded to have widely varying properties. Due to its outstanding mechanical properties and good crack growth resistance, NR is an indispensable material for pneumatic tires, for heavy duty usage and rubber bearings for seismic isolation. It is widely used in shock and vibration isolators because of its high resilience and high tensile and tear properties. Many applications of NR demand products with both excellent strength and outstanding elastic properties. The mechanical properties of rubber as a soft material mostly depend on reinforcement by fillers; thus, the strength to elasticity ratio, when conventional fillers are used, is usually governed by the amount of filler. On the other hand, the property that is significant in the design of structures and mechanical devices is the energy dissipating capacity. It is important, for example, in problems involving mechanical resonance and fatigue, shaft whirl, heating and cyclic stress. Unfilled rubber has very low energy dissipating capacity, but depending on the compound, type and quantity of the filler and vulcanization system used, this property can be significantly varied. For conventional fillers, such as carbon black and silica, which are used in bulk quantities, the general rule is that the strength of rubber increases with the amount of filler, while the elasticity decreases. Nowadays, NR-based nanocomposites, among which those containing layered silicates and carbon nanotubes [1-4] are of major interest, have attracted much attention, due to their enhanced properties at considerably less filler content compared with those of conventional NR compounds. These improvements in mechanical properties, thermal behavior, abrasion resistance, gas permeability etc., are especially remarkable when good and even dispersion of the filler on a nano-level within the rubber matrix is achieved [5-7].

Among the layered silicates, montmorillonite (MMT) is the mostly used for the preparation of polymer nanocomposites due to its large availability, low cost, high surface area and high cation exchange capacity. However, one of the drawbacks of using pristine MMT in NR is its hydrophilic nature, which makes it incompatible with the hydrophobic elastomeric matrix. Thus, the melt mixing of pristine montmorillonite with natural rubber led to composites with undispersed agglomerates [8]. As a result, a lot of research efforts have been focused on the modification of the nanofiller surfaces, which in general include ion exchange reaction of interlayer cations of clay with those of different organic, mainly alkyl amine, surfactants. Another factor influencing the dispersion of the layered silicates, even of those organicallymodified (OMMT), is the polarity of the elastomer. Good dispersion of conventional organomodified montmorillonite (OMMT) in polar elastomeric matrices has been successfully achieved due to interactions between the matrix and polar nanoclay surfaces $[9,10]$. On the other hand, the dispersion of such OMMT is rather unsatisfactory in nonpolar elastomeric matrices such as NR [11, 12], EPDM $[13,14]$ etc., owing to the absence of any feasible filler/matrix interactions.

In order to achieve the desired dispersion of nanofillers, various methods for obtaining elastomeric nanocomposites, similar to those applied for thermoplastics-based nanocomposites, have been used, such as solution mixing [15-17], latex compounding [18-20] and melt mixing [21-24]. Among these, melt mixing is the most widely used due to its simplicity and potential industrial applicability.

Despite the existence of a number of relevant publications in this specific field, there is still an essential need to identify an easy, efficient, economical, ecological and industrially viable way of dispersing the clay nanofillers in different elastomeric matrices without significantly altering the processing conditions and existing manufacturing facilities. Another question that still remains open is how to maintain the supposed previously achieved good nanofiller dispersion during the process of vulcanization, especially when producing large rubber samples.

In the present work, NR/OMMT nanocomposites were prepared by melt mixing, and their basic properties were compared to NR/N330 vulcanizates. From the obtained results, the optimal concentration of OMMT was determined, and bulk $\mathrm{NR} / \mathrm{OMMT} /$ steel samples were produced in order 
to get a better understanding of the influence of the low OMMT content on the dynamic moduli and energy dissipating capacity of bulk NR nanocomposite samples.

Usually, Dynamic Mechanical Analysis (DMA) is used for determining the dynamic modulus, and the weight of the rubber samples tested is approximately $1.2 \mathrm{~g}$. The samples that we investigated weighed $2400 \mathrm{~g}$ (without the steel plates). This requires a specific production and testing procedure.

The viscoelastic properties of rubber allow it to maintain a constant shape after deformation, while simultaneously absorbing mechanical energy [25]. The dynamic properties (or viscoelasticity) of a rubber compound are often determined by measuring its response to a sinusoidally varying strain, using the forced vibration method [25], which enables the energy dissipating capacity to be determines. The results of these measurements performed on bulk samples of NR/OMMT nanocomposites, to our knowledge, are reported for the first time in this work.

\section{EXPERIMENTAL}

\subsection{Materials}

Natural rubber (Malaysian Rubber under the trade name SMR CV 60 with Moony Viscosity, ML (1+4) $\left.100^{\circ} \mathrm{C} 60\right)$ was supplied by Alma Rubber Estates (Malaysia). Commercial organoclay Cloisite 20A was supplied by Southern Clay Products Inc. (USA). The clay contained $95 \mathrm{meq} / 100 \mathrm{~g}$ dimethyl dihydrogenated tallow ammonium (2M2HT). Hydrogenated tallow consists of approximately $65 \%$ $\mathrm{C} 18,30 \% \mathrm{C} 16$ and 5\% C14 fractions and is among the most hydrophobic fillers of the Cloisite series, due to the presence of long hydrocarbon chains in the organic modifier. The rubber compounding ingredients were commercial grades: zinc oxide produced by Grillo Zinkoxid (Germany), stearic acid produced by Pt. Sumi Asih - Bekasi (Indonesia), Santoflex 6PPD ( $N$-(1,3-dimethylbutyl)- $N$ '-phenyl$p$-phenylenediamine), Perkacit TMTD (tetramethyl disulfide) produced by Flexsys (Belgium), Vulkacit $\mathrm{CZ} / \mathrm{C} \quad(N$-cyclohexyl-2-benzothiazolesulfenamide) produced by Lanxess (Germany), and sulfur produced by Siarkopol Tarnobrzeg (Poland).

\subsection{Preparation of NR/OMMT nanocomposites - laboratory-sized and bulk samples}

Rubber compounds were prepared at room temperature in an open two roll mixing mill with a 1 liter capacity. The rubber compounds for the bulk NR/OMMT samples were produced in two roll mill with 10 liters capacity. The formulations used for the preparation of rubber nanocomposites are given in Table 1.

The formulation of the referent NR/N330 sample has been kept confidential. Masticated NR was primarily mixed with $\mathrm{ZnO}$, stearic acid and 6PPD, followed by the incorporation of OMMT. Finally, vulcanization ingredients were added at the end of the mixing process.

Table 1

Formulation of natural rubber compounds

\begin{tabular}{|c|c|c|c|c|c|c|}
\hline \multirow{3}{*}{ Ingredient } & \multicolumn{6}{|c|}{ Sample code } \\
\hline & NR/OMMT-0 & NR/OMMT-2 & NR/OMMT-5 & NR/OMMT-8 & NR/OMMT-10 & NR/OMMT-14 \\
\hline & \multicolumn{6}{|c|}{ phr $^{\mathrm{a}}$} \\
\hline 1. SMR CV 60 & 100 & 100 & 100 & 100 & 100 & 100 \\
\hline 2. $\mathrm{ZnO}$ & 5 & 5 & 5 & 5 & 5 & 5 \\
\hline 3. Stearic acid & 1 & 1 & 1 & 1 & 1 & 1 \\
\hline 4. $6 P P D^{b}$ & 1 & 1 & 1 & 1 & 1 & 1 \\
\hline 5. OMMT $^{\mathrm{c}}$ & $\mathbf{0}$ & 2 & 5 & 8 & 10 & 14 \\
\hline 6. $\mathrm{CBS}^{\mathrm{d}}$ & 1.5 & 1.5 & 1.5 & 1.5 & 1.5 & 1.5 \\
\hline 7. TMTD $^{\mathrm{e}}$ & 0.2 & 0.2 & 0.2 & 0.2 & 0.2 & 0.2 \\
\hline 8. Sulphur & 1.5 & 1.5 & 105 & 1.5 & 1.5 & 1.5 \\
\hline TOTAL: & 110.2 & 112.2 & 115.2 & 118.2 & 120.2 & 124.2 \\
\hline
\end{tabular}

a Parts per hundred parts of rubber

$N$-(1,3-dimethylbutyl)- $N$ '-phenyl- $p$-phenylenediamine

Organomodified montmorillonite - Cloisite 20A

d $N$-cyclohexyl-2-benzothiazolesulfenamide

e Tetramethyl disulfide 
T a ble 2

Technological parameters of compound mixing on two-roll mill with 1 liter capacity

\begin{tabular}{lcc}
\hline \hline Mixing order & $\begin{array}{c}\text { Gap between } \\
\text { rolls (mm) }\end{array}$ & $\begin{array}{c}\text { Mixing time } \\
\text { (minute) }\end{array}$ \\
\hline 1. SMR CV 60 & 0.05 & 4 \\
2. ZnO, stearic acid, & 0.5 & 3 \\
6PPD & 0.8 & 5 \\
3. OMMT & 1.8 & 4 \\
4. TMTD, CBS, S & 0.5 & 2 \\
5. Homogenization & & 18 \\
\hline TOTAL TIME / minute
\end{tabular}

The technological parameters of the mixing process for the two-roll mill with 1 liter capacity are given in Table 2 and for 10 liters capacity in Table 3. Rubber compounds were vulcanized at $145^{\circ} \mathrm{C}$ in a hydraulic press.

\section{Table 3}

\section{Technological parameters of compound mixing} on two-roll mill with 10 liters capacity

\begin{tabular}{llc}
\hline Mixing order & $\begin{array}{c}\text { Gap between } \\
\text { rolls (mm) }\end{array}$ & $\begin{array}{c}\text { Mixing time } \\
\text { (minute) }\end{array}$ \\
\hline 1. SMR CV 60 & 2 & 5 \\
2. ZnO, stearic acid, & 2 & 6 \\
6PPD & 2 & 15 \\
3. OMMT & 2 & 2 \\
4. TMTD, CBS, S & 1.6 & 3 \\
5. Homogenization & & 31 \\
\hline TOTAL TIME / minute & & \\
\hline \hline
\end{tabular}

\subsection{Cure characteristics of the compounds}

Vulcanization characteristics were measured by the Monsanto Oscillating Disk Rheometer (Model R-100) at $145^{\circ} \mathrm{C}$ according to ISO 3417. The disc was oscillated through an arc of $3^{\circ}$. The force, or torque, required to oscillate the disc was recorded as a function of time. The test variable recorded from rheometer were: $M_{L}-$ minimum torque $(\mathrm{dNm}) ; M_{H}-$ maximum torque $(\mathrm{dNm}) ; \Delta M=$ $M_{H}-M_{L}$ - difference between maximum and minimum torque values; $t_{\mathrm{S} 2}-\mathrm{scorch}$ time (minutes); and $t_{90}-$ optimum cure time (minutes).

\subsection{Mechanical characterization}

Tensile and tear tests were performed on a Zwick Roell Dynamometer at a crosshead speed of $500 \mathrm{~mm} / \mathrm{min}$. The samples were cut from vulca- nized plaques in a dumbbell shape. Tensile strength, elongation at break, and modulus 100 and 300 were measured. Measurements of these mechanical properties were conducted according to ISO 37. Three tests were carried out for each sample and results were averaged; minimum and maximum values are also presented.

Shore A hardness was measured by using a Zwick durometer according to ISO 7619-1.

\subsection{Thermal analysis (TGA)}

A Perkin-Elmer Pyris Diamond thermogravimetric analyser (TG/DTA) was used to determine the thermal stability of the nanocomposites. The weight of the samples was in the range of 14$16 \mathrm{mg}$. The samples were heated at a heating rate of $10^{\circ} \mathrm{C} / \mathrm{min}$ from 25 to $800^{\circ} \mathrm{C}$ in air atmosphere using ceramic pans.

\subsection{X-ray diffraction}

X-ray diffraction patterns were recorded by a Rigaku Ultima IV diffractometer. The x-ray beam was Ni-filtered $\mathrm{Cu} K_{\alpha}(\lambda=0.154 \mathrm{~nm})$, and the radiation operated at a tube voltage of $40 \mathrm{kV}$ and a tube current of $40 \mathrm{~mA}$. The samples were scanned at a scan rate of $0.02^{\circ} / \mathrm{min}$ in a range of $2 \theta$ $=0.4^{\circ}-10^{\circ}$ and $2 \theta=5.3^{\circ}-80^{\circ}$. The interlayer spacing was calculated via the Bragg's equation:

$$
\lambda=2 d \sin \theta,
$$

where $\lambda$ is the $\mathrm{x}$-ray wavelength of $0.154 \mathrm{~nm}, d$ is the interlayer spacing, and $\theta$ is the diffraction angle.

\subsection{Swelling behavior}

Samples of approximately $20 \mathrm{~mm} \times 10 \mathrm{~mm}$ $\times 2 \mathrm{~mm}$ were used to determine the swelling behavior. The samples were immersed in toluene, and then periodically removed from the test bottles, the adhering solvent was cleaned from the surface, and the samples were weighed immediately and then placed in toluene again. The mass-swelling ratio $\left(Q_{t}\right)$ was determined from the mass of the sample in the unswollen and swollen states:

$$
Q_{t}=\frac{\left(M_{t}-M_{0}\right)}{M_{0}} 100 \%,
$$

where $M_{0}$ and $M_{t}$ are the mass of the sample before and after swelling. 


\subsection{Measurement of dynamic properties of bulk NR/OMMT compound}

From the results obtained from the first part of experimental investigation, the optimal concentration of OMMT was chosen to be between $2 \mathrm{phr}$ and $8 \mathrm{phr}$, so bulk samples were produced from an NR compound containing 5 phr OMMT. The dynamic properties were investigated by the method of forced vibrations. The apparatus used was custom-made for the Institute of Earthquake Engineering and Engineering Seismology (IZIIS) in Skopje for the purpose of investigating materials suitable for seismic application. Bulk NR/OMMT-5/steel samples with dimensions of $200 \mathrm{~mm} \times 200 \mathrm{~mm} \times$ $50 \mathrm{~mm}$ (Fig. 1) were vulcanized in a hydraulic press. Two samples were placed in a "sandwich" arrangement and subjected to cyclical shear by the displacement of a central push-rod (Fig. 2). The tests were performed in two modes. In the first mode, the strain amplitude was kept constant at 40 $\mathrm{mm}$ and frequency was varied $(0.3 \mathrm{~Hz}, 0.4 \mathrm{~Hz}$ and $0.5 \mathrm{~Hz}$ ). In the second, the frequency was kept constant at $0.3 \mathrm{~Hz}$ and the strain amplitude was varied from $70 \mathrm{~mm}$ to $10 \mathrm{~mm}$.

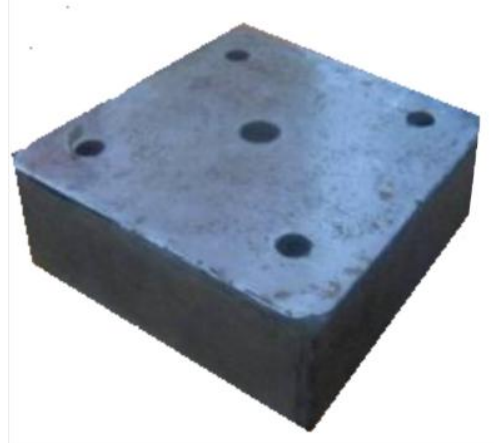

Fig. 1. NR/OMMT-5/steel sample

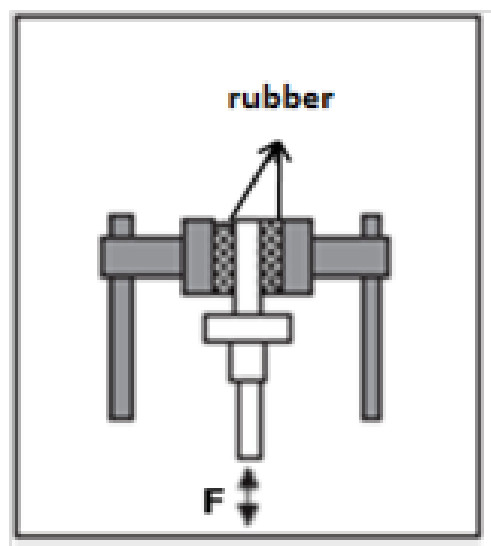

Fig. 2. Schematic view of the apparatus in shear test arrangement
The energy loss per cycle, $E$, was calculated according standard DIN 53513 (Determination of the viscoelastic properties of elastomers on exposure to forced vibration at non-resonant frequencies) as:

$$
E=\frac{\pi}{4} \cdot \Delta F \cdot \Delta L \cdot \sin \delta
$$

where $\Delta F$ is peak to peak force and $\Delta L$ is peak to peak deformation.

The phase angle was calculated as:

$$
\delta=\Delta t \cdot f \cdot 360^{\circ},
$$

where $f$ is the oscillating frequency.

The storage modulus $G^{\prime}$ and loss modulus $G^{\prime \prime}$ were calculated by the equations:

$$
\begin{aligned}
& G^{\prime}=\frac{\Delta F}{\Delta L} \cos \delta, \\
& G^{\prime \prime}=\frac{\Delta F}{\Delta L} \sin \delta
\end{aligned}
$$

The value of $\tan \delta$ (the ratio of the viscous to the elastic response) is a measurement of damping or hysteresis. A comparison was made with samples prepared from a referent NR compound filled with N330 carbon black.

\section{RESULTS AND DISCUSSION}

\subsection{Vulcanization characteristics of the compounds}

The rheometric curves of the unfilled and filled NR compounds are shown in Figure 3.

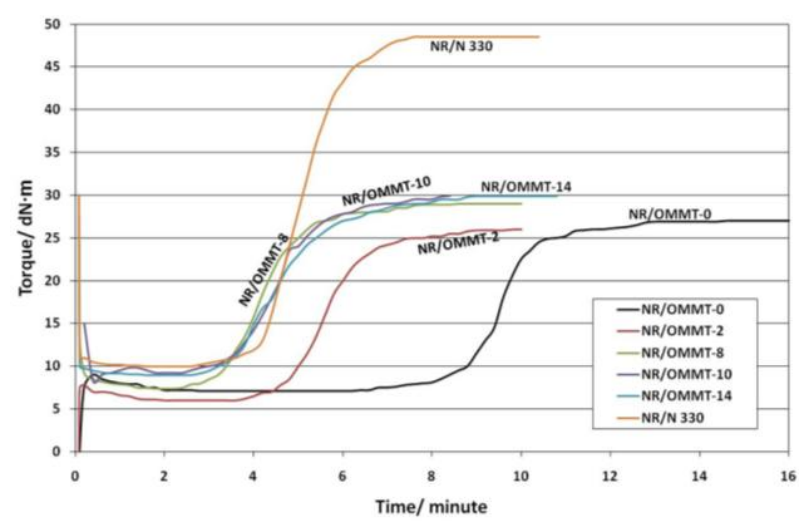

Fig. 3. Rheometric curves of NR compounds 
The vulcanization characteristics: minimum torque $M_{L}$, maximum torque $M_{H}$, scorch time $t_{\mathrm{S} 2}$, optimum cure time $t_{90}$, and difference between maximum and minimum torque values $\Delta M=M_{H^{-}}$ $M_{L}$ were derived from the rheometric curves and are summarized in Table 4.

Table 4

Vulcanization characteristics of NR compounds

\begin{tabular}{lccccccc}
\hline \hline Sample & $\boldsymbol{T}_{\mathbf{0}} /{ }^{\circ} \mathbf{C}$ & $\begin{array}{c}\boldsymbol{M}_{\boldsymbol{L}} \\
(\mathbf{d N m})\end{array}$ & $\begin{array}{c}\boldsymbol{M}_{\boldsymbol{H}} \\
(\mathbf{d N m})\end{array}$ & $\begin{array}{c}\boldsymbol{\Delta} \boldsymbol{M} \\
(\mathbf{d N m})\end{array}$ & $\begin{array}{c}\boldsymbol{t}_{\mathbf{S 2}} \\
(\mathbf{m i n})\end{array}$ & $\begin{array}{c}\boldsymbol{t}_{\mathbf{9 0}} \\
(\mathbf{m i n})\end{array}$ & $\begin{array}{c}\boldsymbol{t}_{\mathbf{v u l}} \\
(\mathbf{m i n})\end{array}$ \\
\hline NR/OMMT-0 & & 7.10 & 27.00 & 19.9 & 8.70 & 10.60 & 12.60 \\
NR/OMMT-2 & & 6.00 & 26.00 & 20.0 & 4.75 & 7.00 & 9.00 \\
NR/OMMT-8 & \multirow{2}{*}{145} & 7.50 & 29.00 & 21.5 & 3.30 & 5.75 & 7.75 \\
NR/OMMT-10 & & 9.30 & 29.50 & 20.2 & 3.25 & 5.75 & 7.75 \\
NR/OMMT-14 & & 9.00 & 30.00 & 21.0 & 3.50 & 6.60 & 8.60 \\
NR/N330 & 10.0 & 48.5 & 38.5 & 4.10 & 6.20 & 8.20 \\
\hline \hline
\end{tabular}

From the presented results, it is evident that scorch time and optimum cure time values were sharply reduced in composites containing OMMT in comparison with unfilled NR compounds, although they were very similar to those determined for carbon black filled NR containing $60 \mathrm{phr}$ carbon black. These vulcanization characteristics decreased with increasing OMMT content; an exception to this was the compound NR/OMMT-14 ( $t_{\mathrm{S} 2}$ and $t_{90}$ were slightly higher than those for composites with lower content of OMMT). The reduction in $t_{90}$ values implies that the clay influenced the cure reaction via promoting its rate and increasing the thermal transition of NR. The contribution of OMMT as cure promoting agent has been attributed to the amine groups of the organic modifier [26]. Similarly, decreased scorch time values suggest better heat distribution in the matrix around clay particles with larger surface areas, which can enhance the overall crosslink density [27]. A tendency towards the formation of filler aggregates, resulting in a reduced rubber-filler interfacial area, might be one reason for the deviation observed for the highest clay-content NR/OMMT-14 sample. It should be mentioned that carbon black was also observed to decrease the optimum cure time, but to a smaller extent compared with the clay, and keeping in mind the incomparable lower concentration of OMMT.

The difference between maximum and minimum torque values $\Delta M=M_{H}-M_{L}$, which is assumed to be indirectly related to the crosslinking density [28], is slightly higher for OMMTcontaining composites in comparison with unfilled ones. Nevertheless, according to the $\Delta M$ values, the highest degree of crosslinking is reached in carbon black filled NR compounds that contain 60 phr carbon black.

An increasing trend of the values of $M_{H}$ and $M_{L}$ with the presence of clay could be attributed to the enhanced filler-rubber interactions. For the NR/OMMT nanocomposite containing 2 phr clay, the lowest minimum torque $\left(M_{L}\right)$ value signified lower viscosity and, hence, an improved processability.

Several researchers [29-31] have evaluated the influence of organoclay on the rubber vulcanization characteristics. In general, it has been widely reported in the literature that, regardless of the nature and polarity of the elastomer, the organoclays behave as catalysts, accelerating the vulcanization reaction, simultaneously and sensibly decreasing the scorch time and optimum cure time. The accelerating effect of the organoclay is essentially attributed to the presence of an amine modifier inserted into the clay galleries, since it is well known that amine groups activate the functional groups of the accelerants, giving rise to a synergic effect that leads to a faster and more effective vulcanization reaction [26].

\subsection{X-ray diffraction analysis of NR/OMMT nanocomposites}

X-ray diffraction analysis is often used to identify the degree of clay intercalation, since the intercalation of the polymer and partial exfoliation of the clay layers leads to an increase of the interlayer spacing (which is observed as shifting of the diffraction peaks towards lower values of $2 \theta$ ), and a decrease in the degree of ordering of silicate layers (which is manifested as broader peaks with lower intensity) [32]. On the other hand, the im- 
provement in the properties of polymer/clay nanocomposites is closely related to the dispersion level of the filler and the achieved degree of delamination.

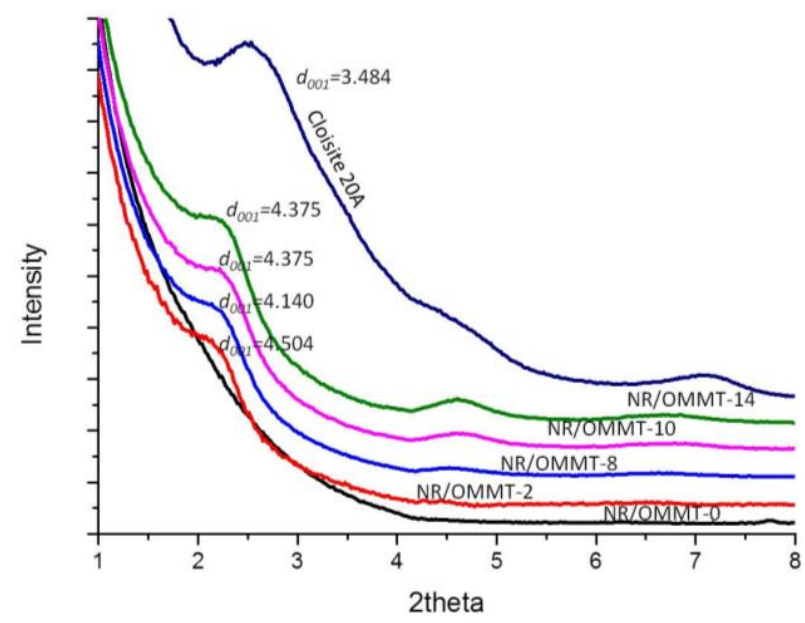

Fig. 4. XRD patterns of the pure Cloisite 20A and NR/OMMT nanocomposites

Figure 4 shows the XRD patterns of the organomodified clay (Cloisite 20A) and NR/OMMT nanocomposites. The values of diffraction angles $2 \theta$ and calculated interlayer distances for Cloisite $20 \mathrm{~A}$ and NR/OMMT nanocomposites are given in Table 5. Cloisite $20 \mathrm{~A}$ shows a diffraction peak at $2 \theta \sim 2.53^{\circ}$, corresponding to an interlayer spacing $d_{001}$ of $3.484 \mathrm{~nm}$.

Table 5

Values of diffraction angles $2 \theta$ and calculated interlayer distances for Cloisite 20A and NR/OMMT nanocomposites

\begin{tabular}{lccc}
\hline \hline & $\left.\mathbf{2 \theta} \mathbf{(}^{\circ}\right)$ & $\mathbf{h k l}$ & $\boldsymbol{d}(\mathbf{n m})$ \\
\hline \multirow{2}{*}{ Cloisite 20A } & 2.532 & 001 & 3.484 \\
& 4.032 & 002 & 2.189 \\
\multirow{2}{*}{ NR/OMMT-2 } & 7.032 & 003 & 1.255 \\
& 1.959 & 001 & 4.504 \\
\multirow{2}{*}{ NR/OMMT-8 } & 4.447 & 002 & 1.984 \\
& 2.173 & 001 & 4.140 \\
\multirow{2}{*}{ NR/OMMT-10 } & 4.525 & 002 & 1.949 \\
& 2.019 & 001 & 4.375 \\
\multirow{2}{*}{ NR/OMMT-14 } & 4.604 & 002 & 1.915 \\
& 2.019 & 001 & 4.375 \\
\hline \hline
\end{tabular}

For the NR/OMMT nanocomposites, the shift in the position of diffraction peak to a lower angle was clearly observed. NR/OMMT-2,
NR/OMMT-8, NR/OMMT-10 and NR/OMMT-14 showed a diffraction peak at $2 \theta=1.959^{\circ}, 2.173^{\circ}$, $2.019^{\circ}$ and $2.019^{\circ}$, which corresponds to a $d_{001}$ spacing of $4.504 \mathrm{~nm}, 4.140 \mathrm{~nm}, 4.375 \mathrm{~nm}$ and $4.375 \mathrm{~nm}$, respectively. These results represent clear evidence of rubber intercalation within the clay platelets, giving rise to an intercalated and, at lower clay loading, partly exfoliated structure. In general, it could be assumed that the level of intercalation was higher for lower clay content.

\subsection{Mechanical properties}

The overall mechanical properties of $\mathrm{NR} /$ clay nanocomposites are related to their structure on the nano-level and to the balance between their reinforcing ability, degree of crosslinking and the dilution effect when the amount of clay is higher. The mechanical properties of NR/OMMT nanocomposites and NR/N330 referent compounds are reported in Table 6 . The hardness of the NR/OMMT compounds increased gradually up to $17 \%$ with the increasing OMMT content from 2 phr to $14 \mathrm{phr}$, as compared to unfilled NR vulcanizate. The tensile properties are given in terms of the modulus for different strains $(100 \%$ and $300 \%$ ), the tensile strength and the elongation at break. It is evident that compound NR/N330 had a significantly higher modulus for a lower strain $(100 \%$ and $300 \%)$. Compared to unfilled NR (NR/OMMT-0), higher $100 \%$ modulus were observed for all nanocomposites, obviously because of the higher crosslink density induced by clay; this corresponds well with the results obtained for delta torque values. The tensile strength of NR/OMMT compounds was higher for those containing a lower content of OMMT. The nanocomposite with 2 phr OMMT (NR/OMMT-2) had the highest value of $24.4 \mathrm{MPa}$, which was $29 \%$ higher than the tensile strength of the compound containing $60 \mathrm{phr}$ carbon black (NR/N330).

Carbon black is a well-known reinforcing filler for NR due to the presence of the strong filler-rubber interactions. However, a high content of carbon black gives rise to a marked loss in the elastic behavior of the NR composite, as seen from Table 6. NR/OMMT nanocomposites have significantly higher elongation at break compared to compound NR/N330.

The nanocomposite with $8 \mathrm{phr}$ OMMT (NR/OMMT-8) had the highest value of $710 \%$, which was $69 \%$ higher than that of the NR/N330 compound. 
Table 6

Mechanical properties of the studied compounds

\begin{tabular}{|c|c|c|c|c|c|c|}
\hline \multirow{2}{*}{ Sample } & \multirow{2}{*}{$\begin{array}{c}\text { Statistical } \\
\text { parameters }\end{array}$} & \multicolumn{5}{|c|}{ Mechanical properties } \\
\hline & & $\begin{array}{c}\sigma_{100} \\
(\mathrm{MPa})\end{array}$ & $\begin{array}{c}\sigma_{300} \\
(\mathrm{MPa})\end{array}$ & $\begin{array}{c}\sigma_{\mathbf{m}} \\
(\mathbf{M P a})\end{array}$ & $\begin{array}{c}\varepsilon \\
(\%) \\
\end{array}$ & $\begin{array}{c}\text { Hardness } \\
\text { (ShA) }\end{array}$ \\
\hline \multirow{4}{*}{ NR/OMMT-0 } & $n$ & 3 & 3 & 3 & 3 & 3 \\
\hline & $\langle x\rangle$ & 1.03 & 2.27 & 19.6 & 610 & 41 \\
\hline & $x_{\max }$ & 1.05 & 2.29 & 19.7 & 620 & 42 \\
\hline & $x_{\min }$ & 1.02 & 2.25 & 19.5 & 600 & 40 \\
\hline \multirow{4}{*}{ NR/OMMT-2 } & $n$ & 3 & 3 & 3 & 3 & 3 \\
\hline & $\langle x\rangle$ & 1.22 & 2.68 & 24.4 & 675 & 43 \\
\hline & $x_{\max }$ & 1.24 & 2.70 & 26.7 & 700 & 44 \\
\hline & $x_{\min }$ & 1.20 & 2.66 & 22.1 & 650 & 42 \\
\hline \multirow{4}{*}{ NR/OMMT-8 } & $n$ & 3 & 3 & 3 & 3 & 3 \\
\hline & $\langle x\rangle$ & 1.31 & 2.40 & 20.7 & 710 & 45 \\
\hline & $x_{\max }$ & 1.32 & 2.42 & 22.0 & 720 & 46 \\
\hline & $x_{\min }$ & 1.29 & 2.38 & 19.4 & 700 & 44 \\
\hline \multirow{4}{*}{ NR/OMMT-10 } & $n$ & 3 & 3 & 3 & 3 & 3 \\
\hline & $\langle x\rangle$ & 1.07 & 2.04 & 19.6 & 650 & 46 \\
\hline & $x_{\max }$ & 1.09 & 2.06 & 20.2 & 660 & 47 \\
\hline & $x_{\min }$ & 1.05 & 2.02 & 19.0 & 640 & 45 \\
\hline \multirow{4}{*}{ NR/OMMT-14 } & $n$ & 3 & 3 & 3 & 3 & 3 \\
\hline & $\langle x\rangle$ & 1.08 & 2.16 & 17.7 & 700 & 48 \\
\hline & $x_{\max }$ & 1.10 & 2.18 & 17.9 & 720 & 49 \\
\hline & $x_{\min }$ & 1.06 & 2.14 & 17.5 & 680 & 47 \\
\hline \multirow{4}{*}{ NR/N330 } & $n$ & 3 & 3 & 3 & 3 & 3 \\
\hline & $\langle x\rangle$ & 2.14 & 10.50 & 18.9 & 420 & 61 \\
\hline & $x_{\max }$ & 2.22 & 10.65 & 20.6 & 440 & 62 \\
\hline & $x_{\min }$ & 2.02 & 10.42 & 18.1 & 400 & 60 \\
\hline
\end{tabular}

$n$-number of measurements, $\langle x\rangle-$ mean value, $x_{\min }-$ minimal value, $x_{\max }-$ maximal value

Due to the strong interaction of carbon black with the elastomeric matrix, the rubber sample loaded with high carbon black content showed an increase in strength, but to the detriment of the elastic characteristics of the rubber compound. On the other hand, due to the inorganic nature of the organoclay, its nanoparticles mainly physical absorptions with the elastomer matrix.

This interaction was weaker than in carbon black compound, and hence, the mobility of the rubber chains was higher [33]. In fact, the reinforcing effect of these nanoclay particles with very high aspect ratio was more noticeable at high elongations when they were perfectly dispersed [28] and, due to the applied tension, oriented in direction of the applied forces in the matrix [22]. All nanocomposites exhibit higher elongation at break then unfilled NR/OMMT-0 compound; this improvement may be attributed partially to the plasticizing effect of surfactants that are located at the clay-rubber interface [34].

\subsection{Thermal properties}

The results of TGA analysis are represented in Table 7 and Figure 5. The addition of OMMT in NR compounds shows insignificant differences in the decomposition temperatures up to temperatures at which $50 \%$ of mass loss occurs. For temperatures higher than $350^{\circ} \mathrm{C}$, the maximal rate of thermal decomposition is lower for all nanocomposites compared to NR $\left(1.41 \%{ }^{\circ} \mathrm{C}^{-1}\right.$ for $\mathrm{NR}$ and $0.89 \%{ }^{\circ} \mathrm{C}^{-1}$ for the nanocomposite containing $10 \mathrm{phr}$ OMMT).

Also, higher OMMT content leads to higher decomposition temperatures; this trend is valid up to $10 \mathrm{phr}$ OMMT (Table 8).

The temperature required for $10 \%$ wt. loss in an oxidative environment (air atmosphere) showed a downward tendency with increasing amounts of OMMT. This is most probably due to the elevated thermal degradation of the amine-organic modifier in the clay, as can be assumed from the TG-curve of OMMT. The temperature corresponding to 50\% wt. loss shifted towards a higher level with the in- 
crease in filler content; an exception was NR/OMMT-14, which was an outcome that was possibly related to the tendency to agglomerate, as discussed previously. It is clearly seen that, in gen- eral, the thermal stability of the nanocomposites containing $14 \mathrm{phr}$ of OMMT was much lower, not only compared to the referent NR compound, but also to other nanocomposites.

T a b le 7

Temperatures of different mass loss for NR/OMMT nanocomposites and NR/N330 composite determined from $T G$-curves

\begin{tabular}{ccccccc}
\hline \hline Sample & $\begin{array}{c}\text { NR/ } \\
\text { OMMT-0 }\end{array}$ & $\begin{array}{c}\text { NR/ } \\
\text { OMMT-2 }\end{array}$ & $\begin{array}{c}\text { NR/ } \\
\text { OMMT-8 }\end{array}$ & $\begin{array}{c}\text { NR/ } \\
\text { OMMT-10 }\end{array}$ & $\begin{array}{c}\text { NR/ } \\
\text { OMMT-14 }\end{array}$ & NR/N330 \\
\hline $\boldsymbol{T}_{\boldsymbol{d}}(\mathbf{- 1 \% )}$ & 213.1 & 253.7 & 238.7 & 237.4 & 231.9 & 200.7 \\
$\boldsymbol{T}_{\boldsymbol{d}}(\mathbf{- 2} \%)$ & 264.2 & 273.9 & 264.9 & 264.2 & 259.1 & 246.8 \\
$\boldsymbol{T}_{\boldsymbol{d}}(\mathbf{- 5} \%)$ & 307.7 & 305.5 & 304.3 & 303.8 & 299.1 & 286.7 \\
$\boldsymbol{T}_{\boldsymbol{d}}(\mathbf{- 1 0} \%)$ & 331.5 & 326.9 & 328.6 & 326.8 & 322.3 & 326.3 \\
$\boldsymbol{T}_{\boldsymbol{d}}(\mathbf{- 1 5} \%)$ & 355.5 & 351.6 & 354.8 & 357.7 & 349.2 & 347.9 \\
$\boldsymbol{T}_{\boldsymbol{d}}(\mathbf{- 2 0} \%)$ & 349.3 & 345.9 & 348.7 & 349.3 & 342.4 & 358.5 \\
$\boldsymbol{T}_{\boldsymbol{d}}(\mathbf{- 5 0} \%)$ & 374.8 & 375.5 & 379.6 & 389.6 & 378.9 & 406.9 \\
$\boldsymbol{T}_{\boldsymbol{d}}(\mathbf{- 7 0} \%)$ & 394.2 & 402.7 & 409.4 & 422.6 & 420.6 & 518.8 \\
$\boldsymbol{T}_{\boldsymbol{d}}(\mathbf{- 9 0} \%)$ & 515.4 & 522.2 & 539.9 & 534.6 & $/$ & 565.3 \\
\hline \hline
\end{tabular}

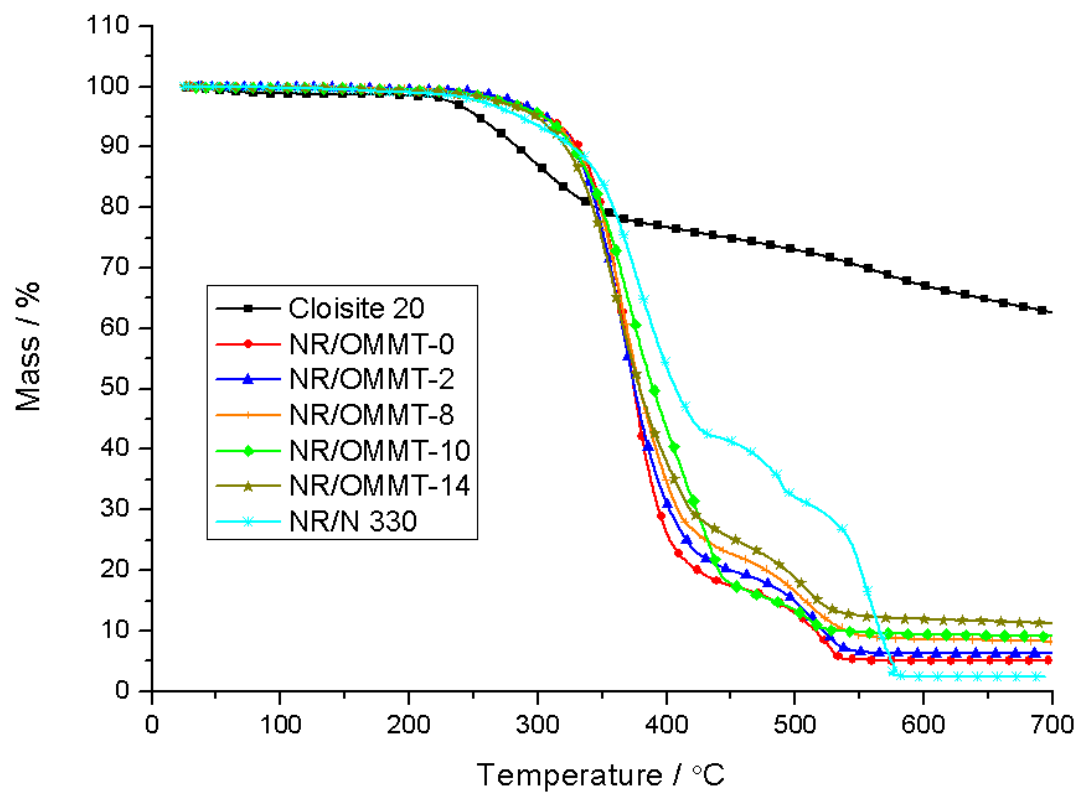

Fig. 5. TGA thermograms

Table 8

Maximal rate of thermal decomposition determined from DTG-curves

\begin{tabular}{lccccc}
\hline \hline Sample & NR/OMMT-0 & NR/OMMT-2 & NR/OMMT-8 & NR/OMMT-10 & NR/OMMT-14 \\
\hline$T_{\max } /{ }^{\circ} \mathrm{C}$ & 375.6 & 363.8 & 366.2 & 375.6 & 364.2 \\
$V_{\max } / \%{ }^{\circ} \mathrm{C}^{-1}$ & $(51 \%)^{*}$ & $(37 \%)$ & $(36 \%)$ & $(38 \%)$ & $(37 \%)$ \\
\hline \hline
\end{tabular}

* Weight loss at $T_{\max }$ 


\subsection{Swelling behavior}

The sorption data of toluene in NR compounds were determined from the mass of the sample in the unswollen and swollen states, according to Equation (2). The mass-swelling ratio $\left(Q_{t}\right)$ at any particular temperature was plotted against the square root of time $(\sqrt{t})$, as shown in Figure 6. The plots show initial increases in the mass of toluene sorbed until the maximum absorption was reached at which time, the mass of the absorbed toluene remained constant; in other words, equilibrium absorption was attained. The swelling ratio decreased with increasing OMMT content compared to unfilled NR compounds. This can be ascribed to a uniform dispersion of OMMT which further forms a physical crosslink with the rubber matrix. The presence of nano-dispersed impermeable OMMT layers with excellent barrier properties decreased the rate of transportation by lengthening the average diffusion path length in NR matrix [35].

An exception represents NR/OMMT-14 nanocomposite, which had the highest swelling ratio; this contributes to the assumption made on the basis of thermal behavior of this particular nanocomposite sample (Table 9).

On the other hand, the results for the referent $\mathrm{NR} /$ carbon black compound were in good correlation with the torque value $(\Delta M)$ reported in Table 4, indicating the highest degree of crosslinking, and hence the best swelling resistance.

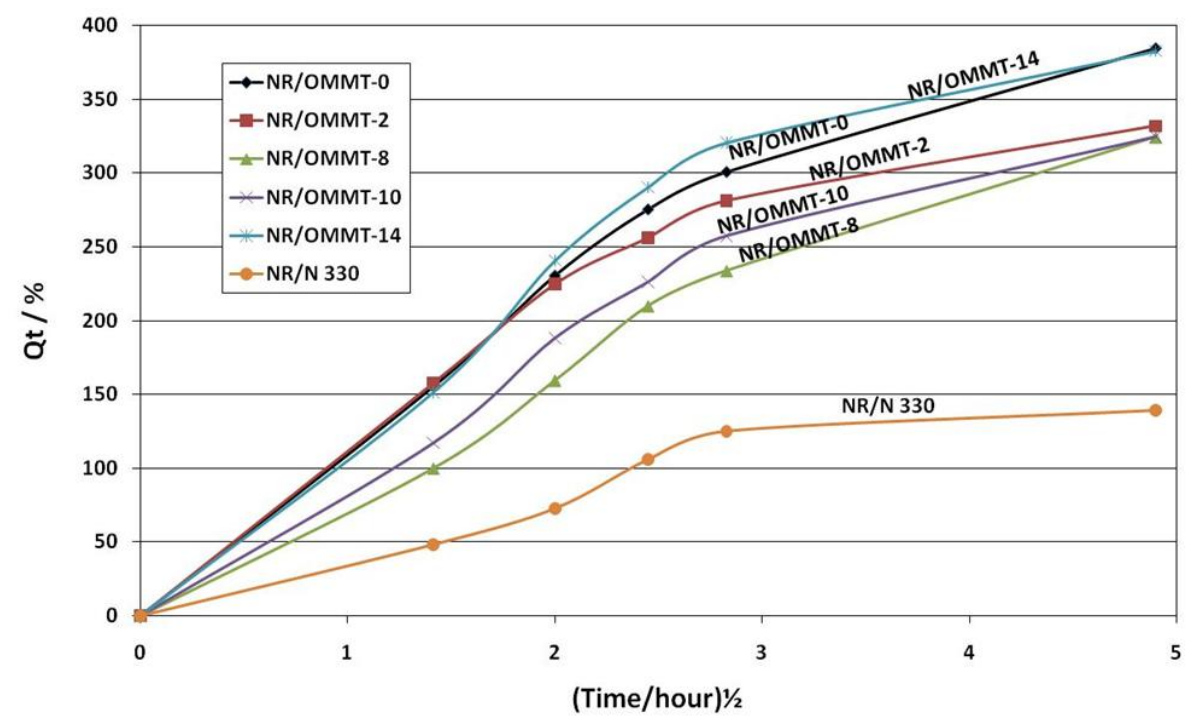

Fig. 6. Plot of sorption data for NR compounds

Ta ble 9

Equilibrium mass-swelling ratio $\left(Q_{24}\right)$

\begin{tabular}{lcccccc}
\hline \hline Sample & NR/OMMT-0 & NR/OMMT-2 & NR/OMMT-8 & NR/OMMT-10 & NR/OMMT-14 & NR/N330 \\
\hline $\boldsymbol{Q}_{24 \mathrm{~h}}(\boldsymbol{\%})$ & 385 & 332 & 324 & 325 & 384 & 139 \\
\hline \hline
\end{tabular}

\subsection{Dynamic properties of bulk NR/OMMT-5 compound}

The majority of rubber performances strongly depend on the viscoelastic properties of filler filled rubber [36]. When carbon black is used as the filler, at filling fractions above a certain threshold, the filler clusters form an irregular network that is fractal on some scales. The main point is that the filler network has the property that it is not stable, but breaks up into smaller units when subjected to loading. It is widely accepted that the fil- ler network is responsible for the typical nonlinear viscoelastic behavior of filled rubbers [37].

Regarding application, it is interesting to investigate the dynamic properties of rubber filled with low quantities of nanofiller, including their frequency and amplitude dependence, and compare them with the behavior of conventional carbon black filled rubber under the same conditions.

The change of the applied force and the deformation with time is shown in Figure 7; also, the hysteresis loop (force vs. deformation) is presented 
for the constant amplitude of deformation of 40 $\mathrm{mm}$ and different frequencies of sinusoidal change of $0.2 \mathrm{~Hz}, 0.3 \mathrm{~Hz}, 0.4 \mathrm{~Hz}$ and $0.5 \mathrm{~Hz}$.
It is obvious that the phase angle between the deformation and the applied force is very low, and, as a result, the loss energy per cycle is also very low.

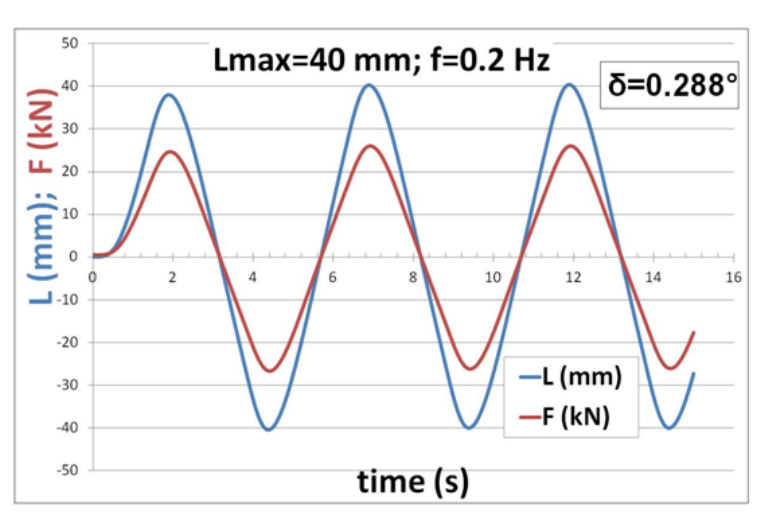

(a)
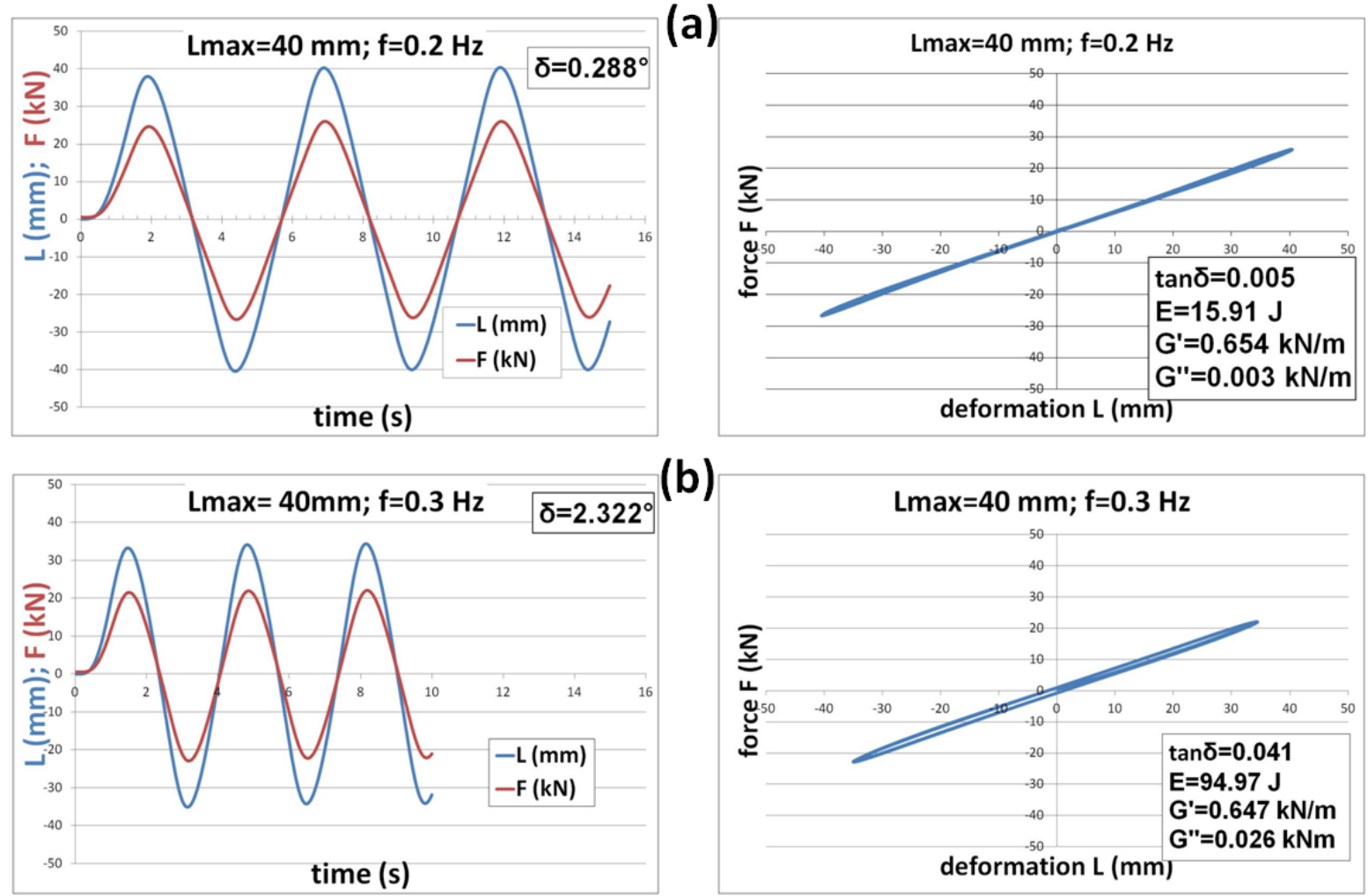

(b)
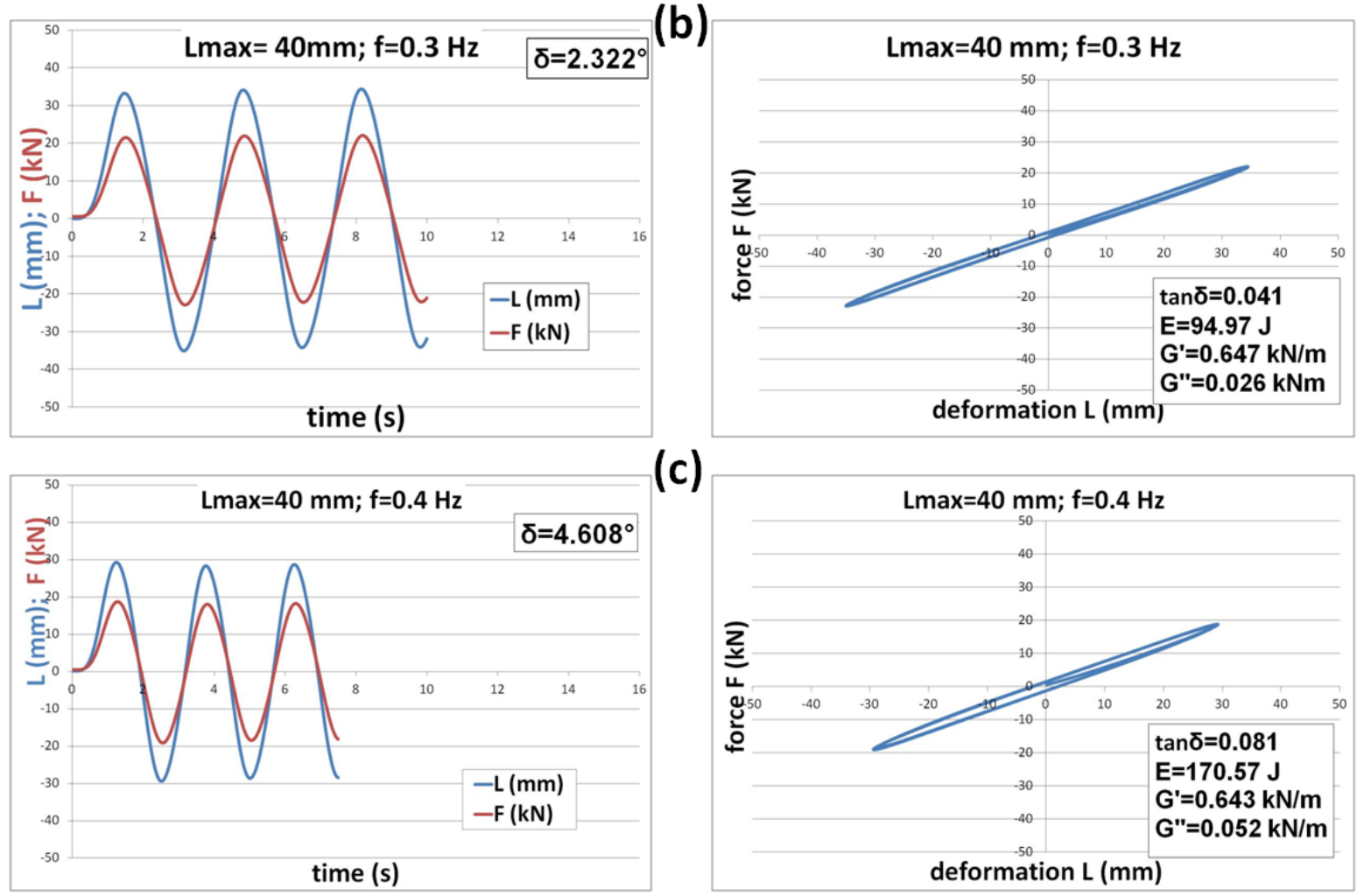

(c)
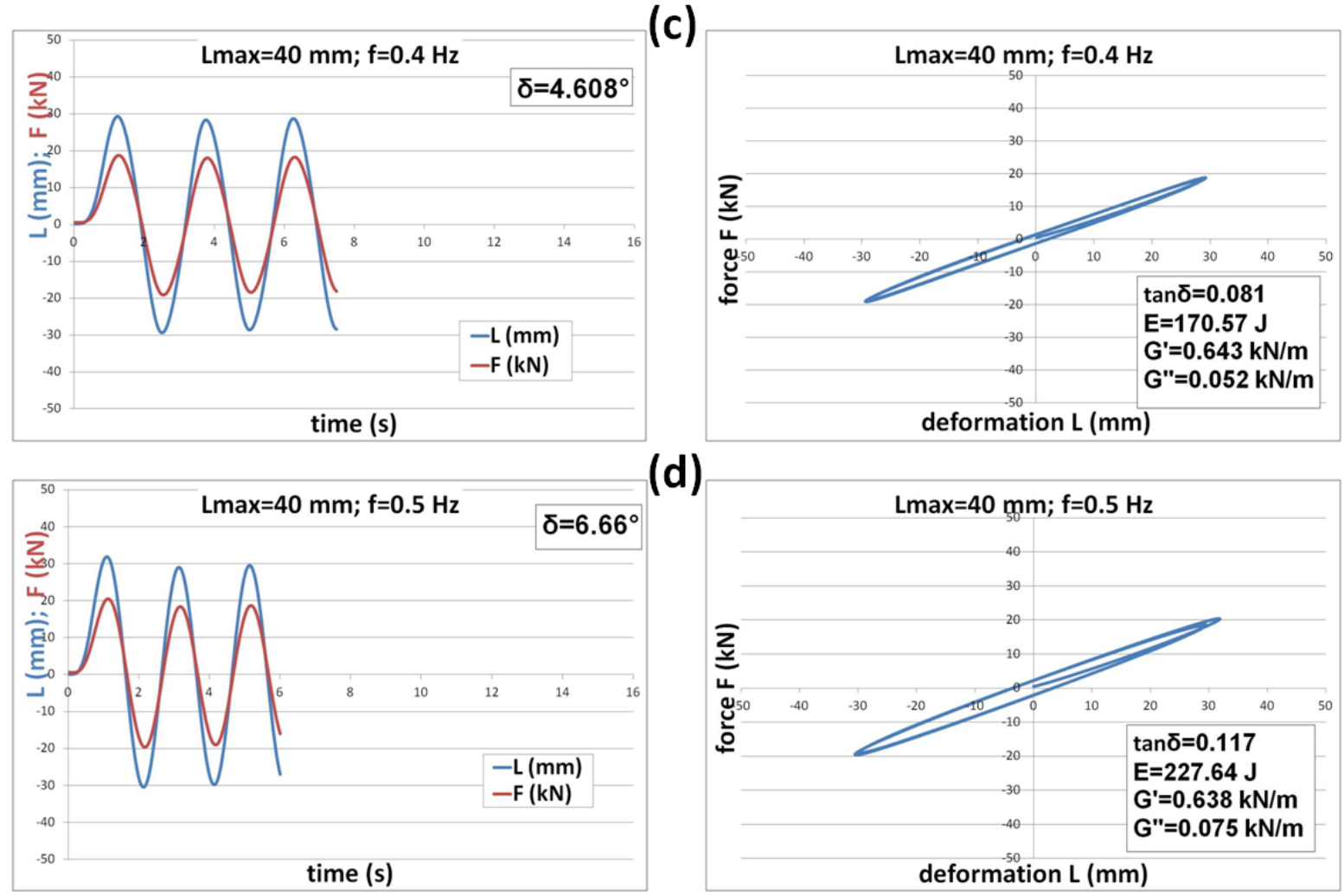

(d)

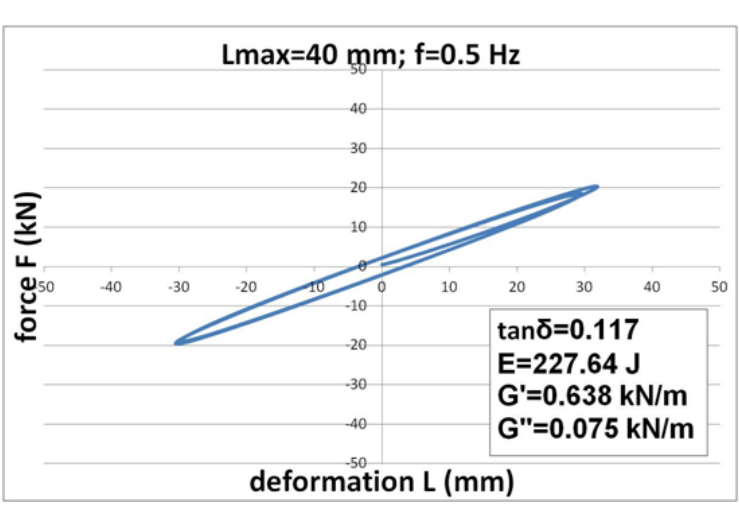

Fig. 7. Force deformation vs. time and hysteresis loops for $L_{\max }=40 \mathrm{~mm}$ and $f=0.2 \mathrm{~Hz}(\mathrm{a}) ; 0.3 \mathrm{~Hz}$ (b); $0.4 \mathrm{~Hz}$ (c); $0.5 \mathrm{~Hz}$ (d) for NR OMMT samples 
Also, it is observed that the energy loss, which is defined by the area of the hysteresis loop, increases with the increasing frequency. This can be seen in Table 10, where the values of $\tan \delta, E, G^{\prime}$ и $G^{\prime \prime}$ for different frequencies are presented.

\section{T a b le 10}

The values of tan $\delta, E, G^{\prime} u G^{\prime \prime}$ for the NR/OMMT-5 sample for the constant amplitude of deformation and different frequencies

\begin{tabular}{ccccc}
\hline \hline $\boldsymbol{f}(\mathbf{H z})$ & $\tan \boldsymbol{\delta}$ & $\boldsymbol{E}(\mathbf{J})$ & $\begin{array}{c}\boldsymbol{G}^{\prime} \\
\left(\mathbf{k N} / \mathbf{m}^{\mathbf{2}}\right)\end{array}$ & $\begin{array}{c}\boldsymbol{G}^{\prime \prime} \\
\left(\mathbf{k N} / \mathbf{m}^{\mathbf{2}}\right)\end{array}$ \\
\hline $\mathbf{0 . 2}$ & 0.005 & 15.91 & 0.654 & 0.003 \\
$\mathbf{0 . 3}$ & 0.041 & 94.97 & 0.647 & 0.026 \\
$\mathbf{0 . 4}$ & 0.081 & 170.57 & 0.643 & 0.052 \\
$\mathbf{0 . 5}$ & 0.117 & 227.64 & 0.638 & 0.075 \\
\hline \hline
\end{tabular}

The loss factor $\tan \delta$ and the energy loss per cycle increase with the increasing frequency. This frequency dependence results from the chain and segment mobility in rubber compounds.

At low frequency, all of the polymer chains in rubber compounds are capable of following deformation without delay. As the frequency of the strain increases, the entanglements of polymers are no longer able to follow the strain during the cycles of deformation [38]. A comparison of the dynamic moduli and loss factor was made with the referent compound reinforced with 60 phr N330 carbon black.

The change in the applied force and deformation with time and hysteresis loop for the referent compound NR/N330 and the compound NR/OMMT-5 are shown in Figure 8 for an amplitude of deformation of $40 \mathrm{~mm}$ and frequency of 0.3 $\mathrm{Hz}$, and in Figure 9 for the same amplitude of deformation and a frequency of $0.4 \mathrm{~Hz}$.

One can observe that the phase shift of the deformation in relation with the applied force is significantly higher for the compound reinforced with carbon black (NR/N330); therefore, the loss factor $\tan \delta$ for NR/N330 was $565 \%$ higher than that for NR/OMMT-5 for $f=0.3 \mathrm{~Hz}$ and $252 \%$ higher for $f=0.4 \mathrm{~Hz}$.

The energy loss per cycle was also significantly higher for the referent compound reinforced with carbon black; this was $1392 \%$ higher than the energy loss per cycle for NR/OMMT-5 sample for $f=0.3 \mathrm{~Hz}$ and $625 \%$ for $f=0.4 \mathrm{~Hz}$. Energy dissipation of the filled rubber subjected to cyclic loading is a result of breaking of the filler network. Higher filler content leads to higher energy dissipated on breaking the filler network.

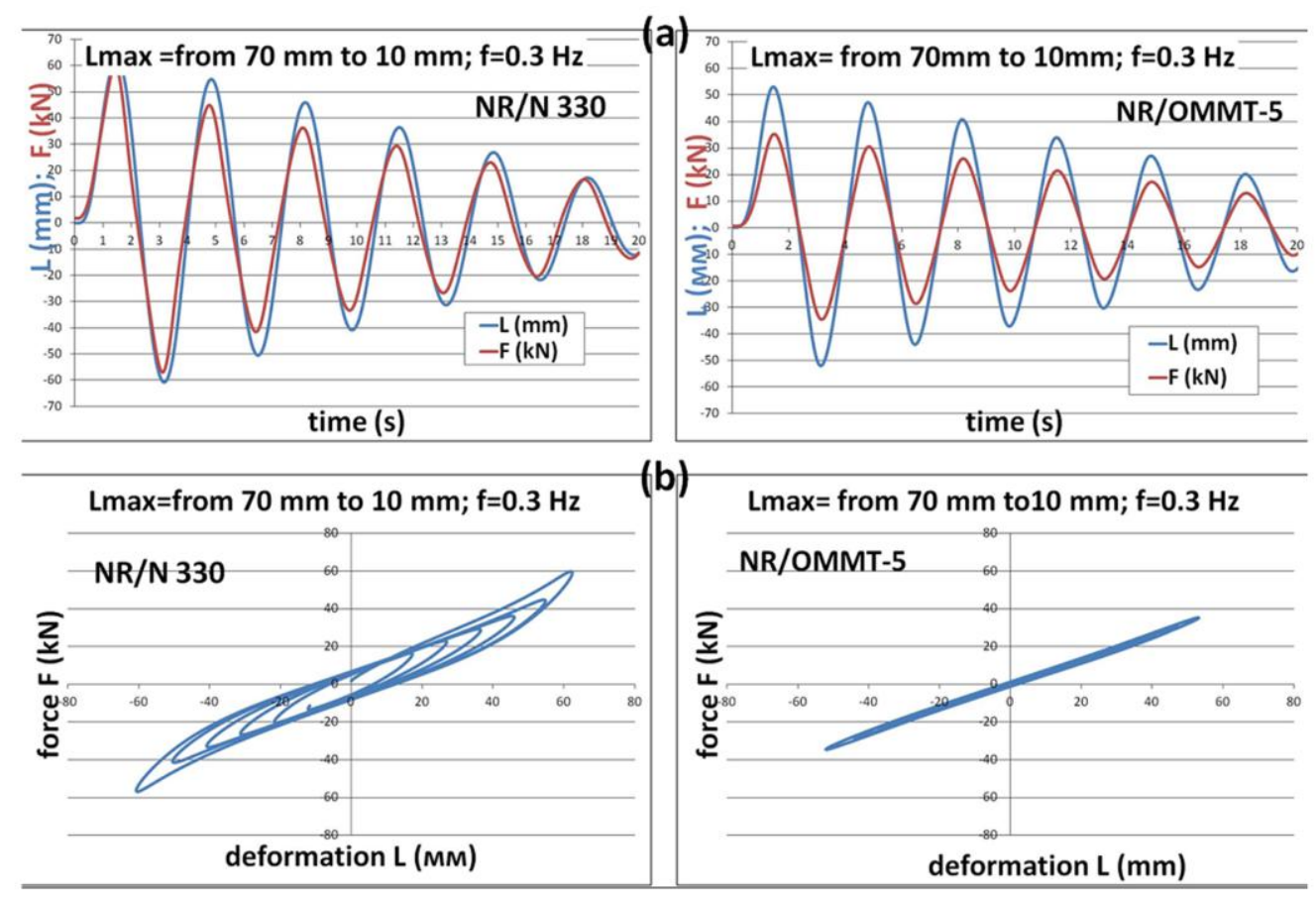

Fig. 8. (a) Force deformation vs. time and (b) hysteresis loops for $L_{\max }=40 \mathrm{~mm}$ and $f=0.3 \mathrm{~Hz}$ for NR/OMMT-5 and NR/N330 samples 

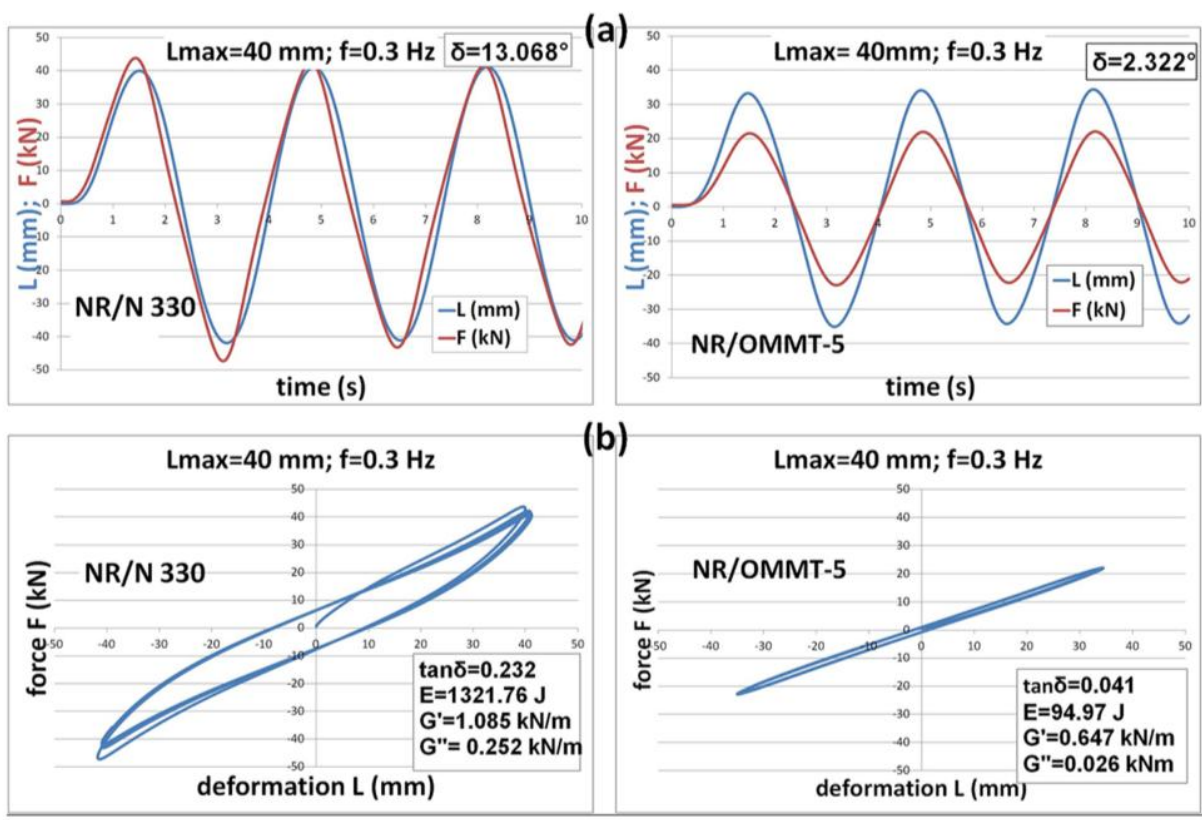

Fig. 9. (a) Force deformation vs. time and (b) hysteresis loops for $L_{\max }=40 \mathrm{~mm}$ and $f=0.4 \mathrm{~Hz}$ for NR/OMMT-5 and NR/N330 samples

Another interesting phenomenon that can be observed from the results presented in Figure 10 and Figure 11 is the Mullins effect or Mullins softening of the rubber. The Mullins effect can be explained as softening of the rubber subjected to big and cyclic loadings. The most evident Mullins softening is in the first cycle, after which it becomes negligible. The Mullins softening could be attributed to a quasiirreversible rearrangement of the molecular network due to local non-affine deformations resulting from a complete extension of the short chains.
During the first extension, local non-affine deformations within the material result in non-affine displacements of molecular network junctions from their initial random state. Then, when the material is stretched for a second time, the network is already in a "preferred" configuration. This is more evident in rubber with higher filler content [39].

The values of $\tan \delta, E, G^{\prime}$ and $G^{\prime \prime}$ for the NR/OMMT-5 and NR/N330 samples for same amplitude of deformation of $40 \mathrm{~mm}$ and frequencies of $f=0.3$ и $0.4 \mathrm{~Hz}$ are shown in Table 11.

Ta ble 11

Tan $\delta, E, G^{\prime}$ and $G^{\prime \prime}$ for NR/OMMT-5 and NR/N330 samples for constant amplitude of deformation of $40 \mathrm{~mm}$ and frequencies of $=0.3$ and $0.4 \mathrm{~Hz}$

\begin{tabular}{c|cccc|cccc}
\hline \hline & \multicolumn{4}{|c|}{ NR/OMMT-5 } & \multicolumn{4}{c}{ NR/N 330 } \\
\hline $\boldsymbol{f}(\mathbf{H z})$ & $\tan \boldsymbol{E}$ & $\boldsymbol{E}(\mathbf{J})$ & $\begin{array}{c}\boldsymbol{G}^{\prime} \\
\left(\mathbf{k N} / \mathbf{m}^{\mathbf{2}}\right)\end{array}$ & $\begin{array}{c}\boldsymbol{G}^{\prime \prime} \\
\left(\mathbf{k N} / \mathbf{m}^{2}\right)\end{array}$ & $\tan \boldsymbol{\delta}$ & $\boldsymbol{E}(\mathbf{J})$ & $\begin{array}{c}\boldsymbol{G}^{\prime} \\
\left(\mathbf{k N} / \mathbf{m}^{\mathbf{2}}\right)\end{array}$ & $\begin{array}{c}\boldsymbol{G}^{\prime \prime} \\
\left(\mathbf{k N} / \mathbf{m}^{2}\right)\end{array}$ \\
\hline 0.3 & 0.041 & 94.97 & 0.647 & 0.026 & 0.232 & 1321.76 & 1.085 & 0.252 \\
0.4 & 0.081 & 170.57 & 0.643 & 0.052 & 0.204 & 1066.29 & 1.302 & 0.265 \\
\hline \hline
\end{tabular}

All of the analyzed parameters have higher values for the rubber reinforced with carbon black.

If we analyze the tendency of their change with frequency (Fig. 10) it can be observed that the loss factor $\tan \delta$ and energy loss per cycle for NR/OMMT-5 sample increase with increasing frequency, as previously discussed. The values of the elastic modulus $G^{\prime}$ vary a little with change of frequency, and can be considered to be constant in this frequency interval. The loss modulus increases slightly with the increase of the frequency. This behavior is in correlation with the information found in the literature regarding this specific matter [39].

The change of applied force and deformation with time is shown in Figure 11; also, the hysteresis loop (force vs. deformation) is presented for a constant frequency of $0.3 \mathrm{~Hz}$, and descending amplitude of deformation from $70 \mathrm{~mm}$ to $10 \mathrm{~mm}$. 

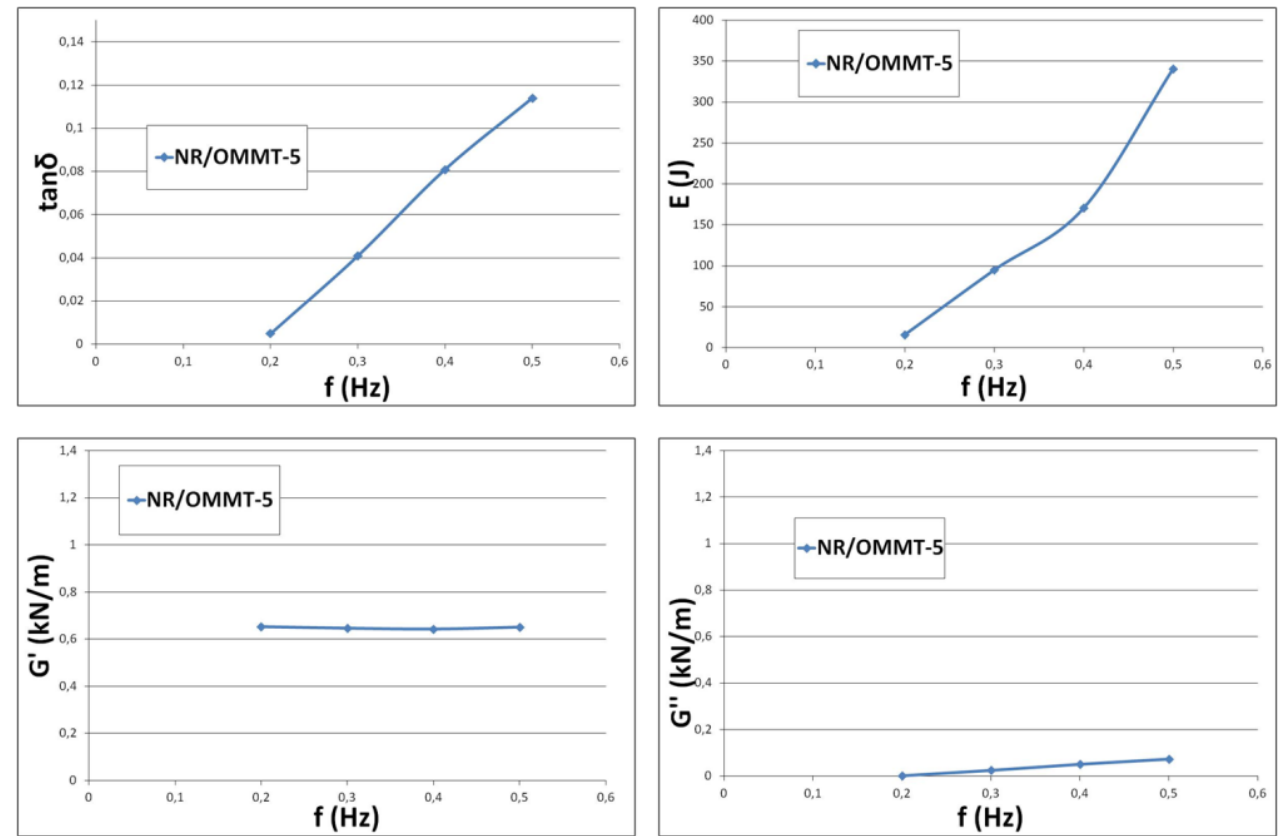

Fig. 10. Dependence of $\tan \delta, E$, $G^{\prime}$ and $G^{\prime \prime}$ from frequency for constant amplitude of $40 \mathrm{~mm}$ for NR/OMMT-5 samples
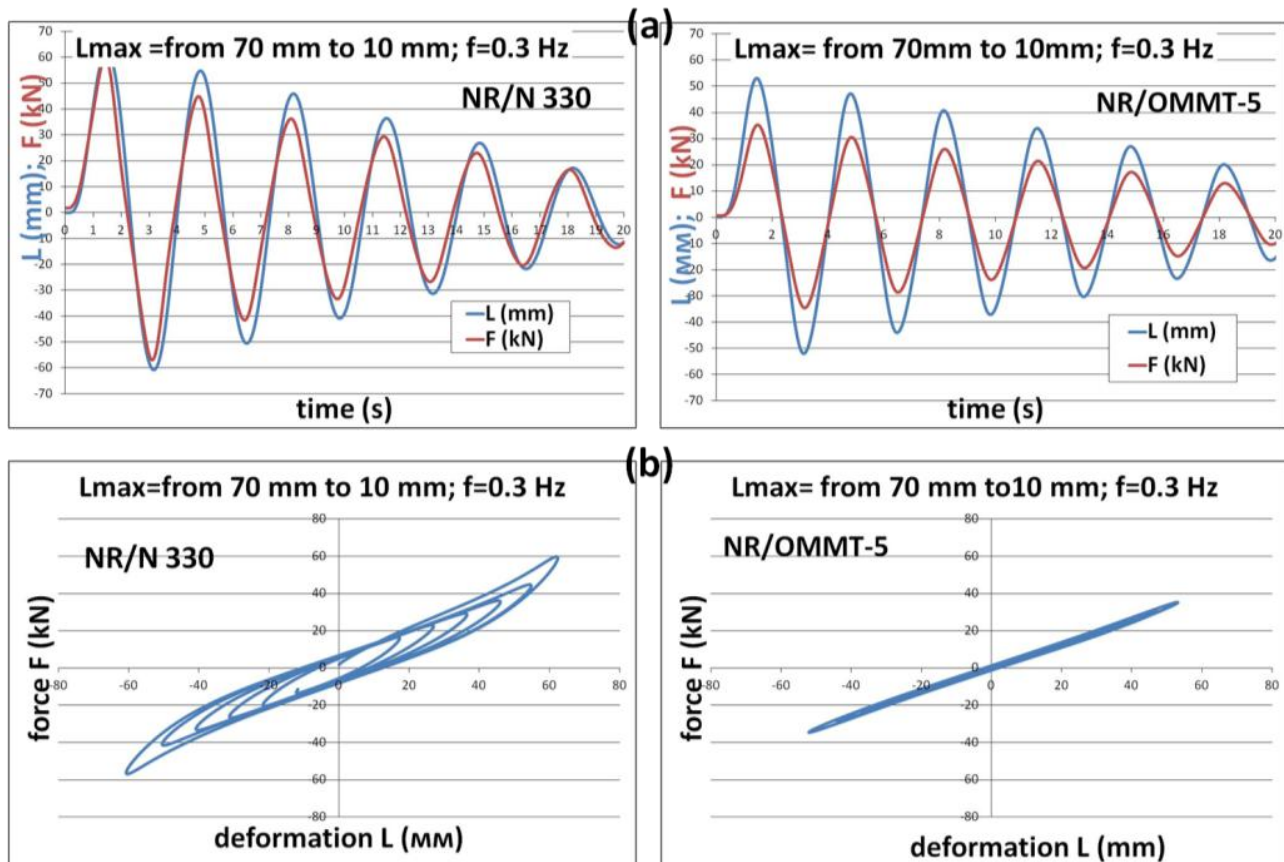

(b)

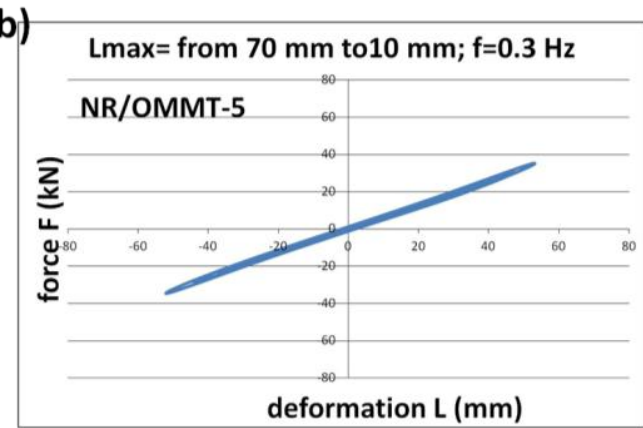

Fig. 11. (a) Force deformation $v s$. time and (b) hysteresis loops for $0.3 \mathrm{~Hz}$ and $L_{\max }$ from $70 \mathrm{~mm}$ to $10 \mathrm{~mm}$ for NR/OMMT-5 and NR/N330 samples

From Figure 11, it can be seen that the phase shift between the deformation and applied force is higher for the NR/N330 sample and it decreases with the increasing amplitude. For lower amplitudes of cyclic loading, the filler network is destroyed and rebuilt. For higher amplitudes, the filler network is irreversibly destroyed. For this reason, the energy that is dissipated upon breaking the filler network is not present for higher amplitudes, because the filler network has already been de- stroyed. As a result, the loss factor, $\tan \delta$, for NR/N 330 sample (Table 12) decreases with an increasing amplitude of deformation. The same tendency was also observed for loss modulus $G^{\prime \prime}$ (Fig. 12).

For the NR/OMMT-5 sample, due to the low content of the nanofiller, the filler network was not formed, so the values of the parameters given in Table 12 and presented in Figure 12, insignificantly change with a decreasing amplitude deformation. 
Table 12

Tand, E, $G^{\prime}$ and $G^{\prime \prime}$ for NR/OMMT-5 and NR/N330 samples for constant frequency and descending amplitude of deformation

\begin{tabular}{l|cccc|cccc}
\hline \hline & \multicolumn{4}{|c|}{ NR/OMMT-5 } & \multicolumn{4}{c}{ NR/N330 } \\
\hline $\boldsymbol{L}_{\text {max }}$ & $\tan \boldsymbol{E}$ & $\boldsymbol{E}(\mathbf{J})$ & $\begin{array}{c}\boldsymbol{G}^{\prime} \\
\left(\mathbf{k N} / \mathbf{m}^{2}\right)\end{array}$ & $\begin{array}{c}\boldsymbol{G}^{\prime \prime} \\
\left(\mathbf{k N} / \mathbf{m}^{2}\right)\end{array}$ & $\tan \boldsymbol{\delta}$ & $\boldsymbol{E}(\mathbf{J})$ & $\begin{array}{c}\boldsymbol{G}^{\prime} \\
\left(\mathbf{k N} / \mathbf{m}^{2}\right)\end{array}$ & $\begin{array}{c}\boldsymbol{G}^{\prime \prime} \\
\left(\mathbf{k N} / \mathbf{m}^{2}\right)\end{array}$ \\
\hline 24.32 & & & & & 0.353 & 551.77 & 0.842 & 0.297 \\
25.23 & 0.051 & 64.72 & 0.636 & 0.032 & & & & \\
32.15 & 0.023 & 46.6 & 0.635 & 0.014 & & & & \\
33.88 & & & & & 0.303 & 864.05 & 0.792 & 0.24 \\
38.99 & 0.042 & 129.33 & 0.638 & 0.027 & & & & \\
43.385 & & & & & 0.262 & 1202.38 & 0.776 & 0.203 \\
45.61 & 0.043 & 183.73 & 0.648 & 0.028 & & & & \\
52.57 & 0.043 & 255.14 & 0.663 & 0.029 & & & & \\
\hline \hline
\end{tabular}
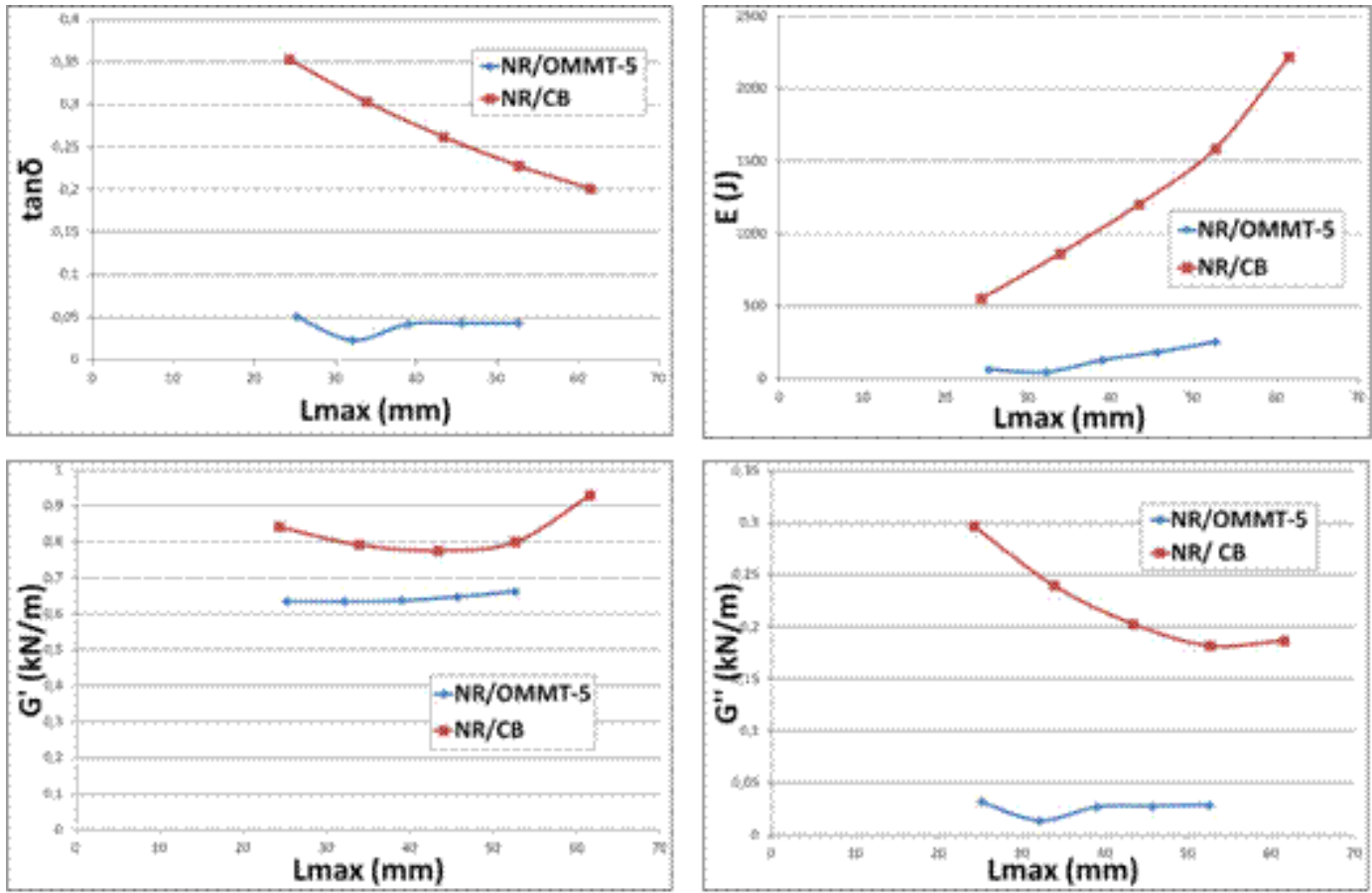

Fig. 12. Dependence of $\tan \delta, E, G^{\prime}$ and $G^{\prime \prime}$ from amplitude for $f=0.3 \mathrm{~Hz}$ for NR/OMMT-5 and NR/N330 samples

\section{CONCLUSIONS}

Natural rubber/organomodified montmorillonite nanocomposites with different OMMT contents were prepared by melt mechanical mixing on standard equipment (open two-roll mill). XRD analysis indicated that the elastomer chains were intercalated with montmorillonite. Organoclay accelerates the vulcanization reaction by decreasing the optimum cure time $\left(t_{90}\right)$ and scorch time $\left(t_{\mathrm{s} 2}\right)$. Furthermore, it gives rise to a higher crosslink density. The addition of organoclay, even at very low content ( $2 \mathrm{phr}$ ), improves the strength of the natural rubber, and at the same time improves the elas- ticity of the composites, which is not the case for carbon black. The nanocomposite containing $2 \mathrm{phr}$ OMMT has tensile strength that is improved by $29 \%$ and elongation at break improved by $61 \%$ in comparison with the referent compound containing $60 \mathrm{phr}$ carbon black.

The investigation of the dynamic moduli of the bulk NR/OMMT-5/steel samples showed improved hysteresis and very low dissipating energy per cycle and significantly reduced Mullins effect in comparison with N330 containing samples.

The obtained results are a solid basis for understanding the influence of OMMT on the dynamic behavior of the rubber and opens up the possibil- 
ity of obtaining hybrid material with controlled energy dissipating capacity.

Acknowledgements. The authors want to thank Prof. Dr. Jasna Djonlagić (Faculty of Technology and Metallurgy, University of Belgrade) for her help with organizing and performing the mechanical testing of the samples.

\section{REFERENCES}

[1] G. Sui, Processing and material characteristics of a carbon-nanotube reinforced natural rubber, Macromol. Mat. Eng., 292(9), 1020-1026 (2007).

[2] L. Bokobza, M. Kolodziej, On the use of carbon nanotubes as reinforcing fillers for elastomeric materials, Polym. Inter., 55(9), 1090-1098 (2006).

[3] M. Kolodziej, L. Bokobza, J. L. Bruneel, Investigations on natural rubber filled with multiwall carbon nanotubes, Comp. Interfaces, 14(3), 215-228 (2007).

[4] Q. Zhao, R. Tannenbaum, K. J. Jacob, Carbon nanotubes as Raman sensors of vulcanization in natural rubber, Carbon, 44(9), 1740-1745 (2006).

[5] S. Rooj, A. Das, K. W. Stöckelhuber, N. Mukhopadhyay, A. R. Bhattacharyya, D. Jehnichen, G. Heinrich, Pre-intercalation of long chain fatty acid in the interlayer space of layered silicates and preparation of montmorillonite/natural rubber nanocomposites. App. Clay Sci., 67-68, 50-56 (2012).

[6] M. Bhattacharyaa, S. Biswasa, S. Bandyopadhyayb, A. $\mathrm{K}$. Bhowmicka, Influence of the nanofiller type and content on permeation characteristics of multifunctional NR nanocomposites and their modeling, Polym. for Advan. Tech., 23(3), 596-610 (2012).

[7] N. Tabsan, S. Wirasate, K. Suchiva, Abrasion behavior of layered silicate reinforced natural rubber, Wear, $\mathbf{2 6 9}$, 394-404 (2010).

[8] K. N. Madhusoodanan, S. Varghese, Technological and processing properties of natural rubber layered silicatenanocomposites by melt intercalation process. J. Appl. Polym. Sci., 102(3), 2537-2543 (2006).

[9] W. G. Hwang, K. H. Wei, C. M. Wu, Mechanical, thermal, and barrier properties of NBR/organosilicate nanocomposites, Polym. Eng. Sci., 44(11), 2117-2124 (2004).

[10] A. Das, R. Jurk, K. W. Stöckelhuber, P. S. Majumder, T. Engelhardt, J. Fritzsche, M. Klüpopel, G. Heinrich, Processing and properties of nanocomposites based on layered silicate and carboxylated nitrile rubber, $J . M a$ cromol. Sci. A Pure Appl. Chem., 46, 7-15 (2009).

[11] A. Das, K. W. Stöckelhuber, R. Jurk, D. Jehnichen, G. Heinrich, A general approach to rubber-montmorillonite nanocomposites: Intercalation of stearic acid, Appl. Clay Sci., 51, 117-125 (2011).

[12] T. Pojanavaraphan, D. A. Schiraldi, R. Magaraphan, Mechanical, rheological, and swelling behavior of natural rubber/montmorillonite aerogels prepared by freezedrying, Appl. Clay Sci., 50, 271-279 (2010).

[13] P. Li, L. Yin, G. Song, J. Sun, L. Wang, H. Wang, Highperformance EPDM/organoclay nanocomposites by melt extrusion, Appl. Clay Sci., 40, 38-44 (2008).
[14] S. Rooj, A. Das, G. Heinrich, Preintercalation of an organic accelerator into nanogalleries and preparation of ethylene propylene diene terpolymer rubber-clay nanocomposites, Polym. J., 243, 285-292 (2011a).

[15] M. A. López-Manchado, B. Herrero, M. Arroyo, Organoclay-natural rubber nanocomposites synthesized by mechanical and solution mixing methods, Polym. Inter., 53(11), 1766-1772 (2004).

[16] Z. Gu, G. Song, W. Liu, B. Wang, J. Li, Preparation and properties of organo-montmorillonite/cis-1,4-polybutadiene rubber nanocomposites by solution intercalation, Appl. Clay Sci., 45(1), 50-53 (2009).

[17] K. Kueseng, K. I. Jacob, Natural rubber nanocomposites with $\mathrm{SiC}$ nanoparticles and carbon nanotubes, Euro. Polym. J., 42(1), 220-227 (2006).

[18] Y. P. Wu, L. Q. Zhang, Y. Q. Wang, Structure of carboxylated acrylonitrile-butadiene rubber (CNBR)-clay nanocomposites by co-coagulating rubber latex and clay aqueous suspensions, J. Appl. Polym. Sci., 82(11), 28422848 (2001).

[19] S. Varghese, J. Karger-Kocsis, Natural rubber-based nanocomposites by latex compounding with layered silicates, Polym., 44(17), 4921-4927 (2003).

[20] Y. P. Wu, Y. Q. Wang, H. F. Zhang, Rubber-pristine clay nanocomposites prepared by co-coagulating rubber latex and clay aqueous suspensions, Comp. Sci. Tech. 65(7-8), 1195-1202 (2005).

[21] S. Varghese, J. Karger-Kocsis, K. G. Gatos, Melt compounded epoxidized natural rubber/layered silicate nanocomposites: structure-properties relationships, Polym., 44(14), 3977-3983 (2003).

[22] S. Joly, G. Garnaud, R. Ollitrault, L. Bokobza. Organically modified layered silicates as reinforcing fillers for natural rubber, Chem. Mat., 14(10), 4202-4208 (2002).

[23] R. Magaraphan, W. Thaijaroen, R. Lim-Ochakun, Structure and properties of natural rubber and modified montmorillonite nanocomposites, Rubb. Chem. Tech., 76(2), 406-418 (2003).

[24] S. Varghese, J. Karger-Kocsis, Melt-compounded natural rubber nanocomposites with pristine and organophilic layered silicates of natural and synthetic origin, $J$. Appl. Polym. Sci., 91(2), 813-819 (2004).

[25] R. J. Schaefer, Mechanical Properties of Rubber, in: Harris' Shock and Vibration Handbook, Sixth edition, A. Piersol, T. Paez (Eds), McGraw-Hill Companies Inc., 2010, pp. 33.1-33.18.

[26] R. Verdejo, M. Hernandez, N. Bitnis, J. M. Kenny, M. A. Lopez-Manchando, Vulcanization characteristics and curing kinetics of rubber-organoclay nanocomposites, in: Rubber Clay Nanocomposites - Science, Technology and Applications, M. Galimberti (ed), New York, Wiley and Sons, 2011, pp. 275-303.

[27] M. A. Kader, K. Kim, Y. S. Lee, C. Nah, Preparation and properties of nitrile rubber/montmorillonite nanocomposites via latex blending, J. Mater. Sci., 41, 73417352 (2006).

[28] M. Arroyo, M. A. López-Manchado, B. Herrero, Organo-montmorillonite as substitute of carbon black in natural rubber compounds, Polym., 44(8), 2447-2453 (2003). 
[29] P. Zhang, G. S. Huang, X. A. Wang, Y. J. Nie, L. L. Qu, The influence of montmorillonite on the anti-reversion in the rubber-cly composites. J. Appl. Polym. Sci., 118(1), 306-311 (2010).

[30] J. Diez, R. Bellas, C. Ramirez, A. Rodriguez, Effects of organoclay reinforcement on the curing characteristics and technological propeties of SBR sulphur vulcanizates. J Appl Polym Sci, 118(1), 556-573 (2010).

[31] L. Ghasemi, M. Karrabi, M. Mohammadi, H. Azizi, Evaluating the effects of processing conditions and organoclay content on the properties of styrene-butadiene rubber/organoclay nanocomposites by response surface methodology. Express Polym. Lett., 4(2), 62-70 (2010).

[32] S. Chakraborty, S. Kar, S. Dasgupta, R. Mukhopadhyay, S. Bandyopadhyay, M. Joshi, S. C. Ameta, Study of the properties of in-situ sodium activated and organomodified bentonite clay - SBR rubber nanocomposites. Part I: Characterization and rheometric properties, Polym. Testing, 29, 81-187 (2010).

[33] M. A. López-Manchado, J. L. Valentin, J. Carretero, F. Barroso, M. Arroyo, Rubber network in elastomer nanocomposites, Euro. Polym. J., 43(10), 4143-4150 (2001).
[34] S. Rooj, A. Das, K.W. Stöckelhuber, N. Mukhopadhyay, A. R. Bhattacharyya, D. Jehnichen. G. Heinrich, Preintercalation of long chain fatty acid in the interlayer space of layered silicates and preparation of montmorillonite/natural rubber nanocomposites, Appl. Clay Sci., 67-68, 50-56 (2012).

[35] G. Zheng, S. Guojun, L. Weisheng, W. Baojin, L. Jin, Preparation and properties of organo-montmorillonite/cis-1,4-polybutadiene rubber nanocomposites by solution intercalation, Appl. Clay Sci., 45, 50-53 (2009).

[36] E. Kazina, O. Starkova, A. Aniskevich, Volume changes in filled rubber under uniaxial cyclic loading, Mat. Sci., 17, 272-275 (2011).

[37] G. Hubery, T. A. Vilgisy, G. Heinrich, Universal properties in the dynamical deformation of filled rubbers, $J$. Phy.: Condense Matter, 8, L409-L412 (1996).

[38] D. E. Hall, J. C. Moreland, Fundamentals of rolling resistance, Rubb. Chem. and Tech., 74 (3), 525-539 (2001).

[39] A. C. Harwood, A. R. Payne, Stress softening in natural rubber vulcanizates, III: Carbon black filled vulcanizates, Appl. Polym. Sci., 10, 315-323 (1966). 
